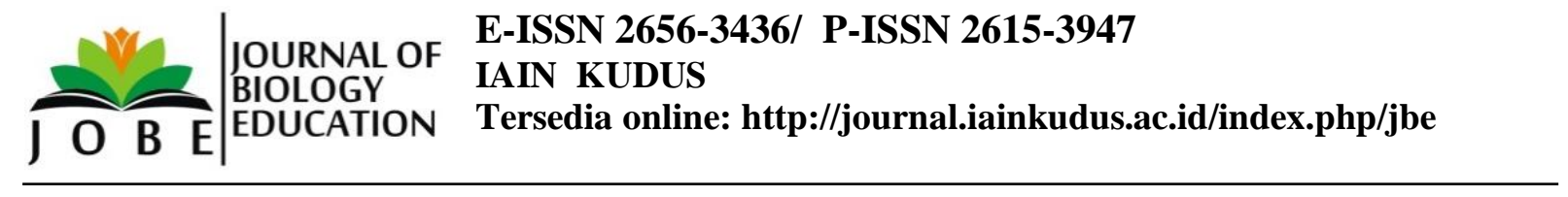

\title{
Analisis Penggunaan Media Power Point dalam Pembelajaran Jarak Jauh pada Materi Animalia Kelas VIII
}

\author{
Lusi Purwanti $^{1}$, Rizki Widyaningrum ${ }^{2}$, Surya Ayu Melinda $^{3}$ \\ Pendidikan Biologi, Fakultas Keguruan dan Ilmu Pendidikan, Universitas Ahmad Dahlan \\ lusipurwanti88@gmail.com, rizzkigiselda17@gmail.com, suryaayumelinda@gmail.com
}

\begin{abstract}
ABSTRAK
Media pembelajaran yang biasa digunakan di SMP Negeri 1 Pandak adalah power point. Peneliti ini dilakukan untuk melihat keefektifan penggunaan media power point pada pembelajaran materi animalia di SMP Negeri 1 Pandak. Penelitian ini merupakan penelitian deskriptif kualitatif. Populasi penelitian adalah seluruh siswa kelas VIII, dan sempel dipilih secara acak sebanyak 25 siswa. Teknik pengumpulan data pada penelitian ini adalah kuisioner, dengan instrument penelitian adalah angket yang diisi oleh siswa melalui Google Form yang dikirimkan melalui whatsapp group kelas. Berdasarkan data hasil penelitian dan pembahasan menunjukan bahwa media pembelajaran power point efektif digunakan dalam Pembelajaran materi animalia kelas VIII di SMP Negeri 1 Pandak.
\end{abstract}

Kata kunci: power point, pembelajaran jarak jauh, materi animalia

\begin{abstract}
The learning media commonly used in SMP Negeri 1 Pandak is Power Point. This researcher was conducted to see the effectiveness of the use of media Power Point in Animalia topic learning at SMP Negeri 1 Pandak. This research is a qualitative descriptive study. The study population was all students of class VIII, and samples were randomly selected as many as 25 students. The data collection technique in this study was a questionnaire, with the research instrument being a questionnaire that was filled out by students via Google Form which was sent via the group WhatsApp class. Based on the data from the research and discussion results, it shows that the learning media is Power Point effectively used in Animalia topic learning for class VIII at SMP Negeri 1 Pandak.
\end{abstract}

Keywords: power point, distance learning, animalia topic 


\section{PENDAHULUAN}

Perkembangan teknologi informasi dan komunikasi saat ini memberikan dampak yang besar dan signifikan terhadap kehidupan manusia. Dalam berbagai aspek kehidupan manusia tidak lepas dari kehadiran teknologi informasi dan komunikasi, salah satunya dalam aspek pendidikan. Dalam aspek pendidikan masyarakat bisa mengakses dengan mudah pengetahuan yang bisa dicari melalui internet. Masyarakat dengan mudah mengakses internet melalui gadget ataupun handphone pintar yang saat ini sudah menjadi barang wajib untuk dimilki setiap orang.

Tahun 2020 saat ini Indonesia dan berbagai negara di belahan dunia lainnya tengah dihadapkan dengan pandemic yang disebabkan oleh virus coronavirus. Coronavirus merupakan virus jenis baru (SARS-CoV-2) dan penyakitnya disebut Coronavirus disease 2019 (COVID-19) yang berasal dari Wuhan, Tiongkok pada akhir Desember 2019 (Yuliana, 2020 : 188). Virus ini dapat ditularkan dari manusia ke manusia dan telah menyebar secara luas di lebih dari 190 negara sehingga pada 12 Maret 2020, WHO mengumumkan COVID19 sebagai pandemic (Susilo et al., 2020 : 45). Pandemi COVID-19 ini memberikan dampak yang besar bagi kehidupan manusia. Dilansir dari detiknews sampai hari ini kasus COVID19 di Indonesia telah menyentuh angka 271 ribu dengan jumlah pasies meninggal sebanyak 10 ribu orang.

Dampak COVID-19 ini menyerang berbagai aspek salah satunya pendidikan. Untuk memutus mata rantai penyebaran COVID-19 di Indonesia, Pemerintah melalui Kemendikbud menerbitkan Surat Edaran Nomor 3 Tahun 2020 tentang Pencegahan COVID-19 pada satuan Pendidikan. Program belajar dari rumah ini telah diterapkan dari berbagai tingkatan pendidikan di Indonesia (Kemendikbud, 2020).

Upaya proses pembelajaran tetap terselenggara, sekolah-sekolah pun memanfaatkan perkembangan teknologi, informasi dan komunikasi yaitu dengan menerapkan pembelajaran daring terlaksana dengan lebih mudah. Daring merupakan pemanfaatan jaringan internet dalam proses pembelajaran (Isman dalam Suswandari, 2016 : 1). Pembelajaran daring menjadi alternatif untuk menyelenggarakan

Pembelajaran daring merupakan kebijakan nasional sebagai langkah strategis dalam upaya pencegahan penyebaran virus COVID-19. Kelebihan pembelajaran daring sendiri 
adalah dapat diakses dimana pun dan kapan pun asalkan terhubung dengan koneksi internet. Oleh karena itu, pembelajaran daring mendukung untuk proses Pembelajaran Jarak Jauh. SMP menggunakan pembelajaran jarak jauh dan dengan metode daring jarang dilakukan.

SMP negeri 1 Pandak merupakan salah satu sekolah yang menerapkan Pembelajaran Jarak Jauh, dalam menunjang Pembelajaran Jarak Jauh SMP Negeri 1 Pandak menggunakan platform digital whatsapp, google form dan website sekolah sebagai media untuk menyampaikan materi kepada siswa.

Adapun media pembelajaran yang biasa digunakan di SMP Negeri 1 Pandak menggunakan power point. Microsoft Power Point merupakan salah satu program berbasis multimedia. Software ini, menyediakan fasilitas dalam bentuk slide-slide yang dapat membantu dalam menyusun suatu presentasi yang efektif, profesional, dan juga mudah. Sehingga memungkinkan para guru sekolah untuk memanfaatkan sebagai media pembelajaran (Azhar, 2017 : 16). Dalam literature lain Mulyawan dalam Maryatun (2015) menyatakan bahwa "Microsoft PowerPoint adalah salah satu jenis program komputer yang tergabung dalam Microsoft Office yang digunakan untuk presentasi dan merupakan program berbasis multimedia".

Berdasarkan hasil penelitian Hikmah (2020) menyatakan bahwa media pembelajaran power point dapat menarik minat belajar siswa sehingga mendapatkan hasil yang memuaskan, sehingga ketika hasil belajar siswa memuaskan maka media pembelajaran yang berupa power point efektif digunakan oleh guru ketika pembelajaran Jarak Jauh.

Perlu untuk diketahui bahwa pembelajaran power point memilki banyak fitur-fitur yang menarik seperti kemampuan pengolah teks, dapat menyisipkan gambar, audio, animasi, efek yang dapat di atur sesuai selera penggunanya, sehingga peserta didik akan tertarik pada apa yang ditampilkan pada power point (Misbahudin dalam Hikmah 2020). Selain itu, pembelajaran menggunakan media power point lebih mudah diakses dan praktis karena tidak memerlukan koneksi internet ketika akan membukanya serta ukuran file yang kecil sehingga tidak memerlukan ruang penyimpanan yang besar.

Aspek kemudahan menggunakan media power point menyebabkan penggunaan media ini menjadi lebih sering digunakan di SMP Negeri 1 Pandak. Oleh karena itu, perlu dilakukan 
penelitian untuk melihat keefektifan penggunaan media power point pada Pembelajaran materi animalia di SMP Negeri 1 Pandak.

Tujuan dari penelitan ini adalah untuk menganalisis efektifitas penggunaan power point pada pembelajaran materi animalia secara daring di SMP Negeri 1 Pandak. Penelitian ini memberi manfaat kepada para guru maupun siswa juga kepada para pembacanya. Bagi para guru, penelitian ini diharapakan meningkatkan kualitas pembelajaran dan mampu mengembangkan kemampuan guru dalam membuat media pembelajaran yang menarik bagi siswa. Bagi para siswa, penelitian ini diharapkan dapat membantu siswa untuk mejadi media menyampaikan permasalahan yang selama ini belum bisa dikatakan, dengan begitu akan mampu menumbuhkan semangat belajar dengan menggunakan media pembelajaran yang lebih menarik dan menyenangkan dalam proses Pembelajaran materi animalia. Kemudian bagi pembaca dapat dijadikan acuan, perbandingan dan referensi untuk mengembangkan media pembelajaran yang lebih baik, menarik dan menyenangkan bagi siswa.

\section{METODE PENELITIAN}

Penelitian ini merupakan penelitian deskriptif kualitatif, Penelitian ini merupakan penelitian kualitatif deskriptif. Penelitian kualitatif deskriptif adalah penelitian yang bertujuan mendesripsikan/ menjabarkan fenomena yang terjadi pada subjek penelitian secara mendalam. Pada penelitian ini fenomena yang diamati adalah keefektifan penggunaan media power point pada Pembelajaran materi animalia kelas VIII. Populasi penelitian adalah seluruh siswa kelas VIII, dan sempel dipilih secara acak sebanyak 25 siswa. Teknik pengumpulan data pada penelitian ini adalah kuisioner, dengan instrument penelitian adalah angket yang diisi oleh siswa melalui Google Form. Angket yang digunakan untuk memperoleh data tentang pendapat siswa mengenai keefektifan penggunaan media power point saat pembelajaran jarak jauh dimasa pendemi COVID 19. Data hasil penelitian dianalisis secara deskriptif kualitatif. 


\section{HASIL DAN PEMBAHASAN}

Berdasarkan hasil kuesioner yang telah diisi oleh 25 siswa kelas VIII SMP Negeri 1 Pandak diperoleh data yang di sajikan dalam Tabel 1, yang berisi nomor pertanyaan serta persentase.

Tabel 1. Data hasil kuisioner siswa kelas VIII dengan penggunakan media power point pada materi Animalia.

\begin{tabular}{cccccc}
\hline No Pernyataan & SS & S & R & TS & STS \\
& \multicolumn{5}{c}{ (Jumlah dalam \%) } \\
\hline 1 & 28 & 60 & 12 & 0 & 0 \\
2 & 32 & 48 & 20 & 0 & 0 \\
3 & 32 & 44 & 20 & 4 & 0 \\
4 & 20 & 44 & 36 & 4 & 0 \\
5 & 16 & 60 & 24 & 0 & 0 \\
6 & 28 & 64 & 12 & 0 & 0 \\
7 & 48 & 44 & 12 & 0 & 0 \\
8 & 36 & 56 & 8 & 0 & 0 \\
9 & 44 & 44 & 8 & 4 & 0 \\
10 & 28 & 64 & 16 & 0 & 0
\end{tabular}

Keterangan :

$$
\begin{array}{ll}
\mathrm{SS} & =\text { Sangat setuju } \\
\mathrm{S} & =\text { Setuju } \\
\mathrm{R} & =\text { Ragu-ragu } \\
\mathrm{TS} & =\text { Tidak setuju } \\
\text { STS } & =\text { Sangat tidak setuju }
\end{array}
$$

Angket yang disebarkan kepada siswa secara online melalui google form yang nantinya dikirmkan melalui whatsapp group kelas. Penggunaan angket ini bertujuan untuk mendapatkan informasi berupa pelaksanaan proses pembelajaran secara dalam jaringan (daring) dengan menggunakan media pembelajaran power point. Berikut adalah pertanyaan dan hasil yang diperoleh di dalam angket yang diajukan kepada siswa. 
1) Saya merasa bersemangat melaksanakan pembelajaran materi animalia dengan media power point.

Berdasarkan Tabel 1 terlihat bahwa siswa lebih banyak menjawab setuju dengan persentase $60 \%$, yang berarti bahwa siswa merasa bersemangat melaksanakan pembelajaran materi animalia dengan media power point.

2) Media power point membantu saya dalam memahami materi pembelajaran materi animalia.

Berdasarkan Tabel 1, untuk pernyataan kedua siswa lebih banyak menjawab setuju dengan persentase $48 \%$ yang menunjukkan bahwa media power point membantu siswa dalam memahami materi Pembelajaran materi animalia.

3) Media power point lebih mudah digunakan dalam proses pembelajaran jarak jauh.

Berdasarkan Tabel 1, siswa lebih banyak menjawab setuju dengan persentase $44 \%$ yang berarti bahwa media power point lebih mudah digunakan dalam proses pembelajaran jarak jauh. Sisi lain terdapat siswa yang tidak setuju jika media power point lebih mudah digunakan dalam proses pembelajaran jarak jauh dengan persentase $4 \%$.

4) Saya merasa lebih mudah memahami materi animalia menggunakan media power point dibandingkan media pembelajaran lain.

Dilihat dari Tabel 1, hasil yang diperoleh juga sama seperti pernyataan ketiga yaitu siswa lebih banyak setuju dengan persentase yang sama yaitu $44 \%$ dan sebanyak $4 \%$ tidak setuju.

5) Saya merasa termotivasi saat guru menjelaskan materi animalia dengan media power point.

Berdasarkan Tabel 1 menunjukkan bahwa siswa lebih banyak setuju yaitu dengan persentase sebesar $60 \%$ yang berarti bahwa siswa merasa dirinya termotivasi saat guru menjelaskan materi animalia dengan media power point.

6) Media power point yang diberikan guru memiliki tampilan yang menarik sehingga membuat saya tertarik.

Berdasarkan Tabel 1 menunjukkan bahwa siswa lebih banyak setuju yaitu dengan persentase sebesar $64 \%$ yang menandakan bahwa media power point yang diberikan guru memiliki tampilan yang menarik sehingga membuat saya tertarik. 
7) Media power point mendukung pembelajaran jarak jauh karena tidak membutuhkan banyak kuota untuk mengaksesnya.

Tabel 1 menunjukkan bahwa siswa setuju jika media power point mendukung pembelajaran jarak jauh karena tidak membutuhkan banyak kuota untuk mengaksesnya dengan besaran persentase yaitu sebesar $44 \%$.

8) Media power point praktis dan mudah digunakan.

Berdasarkan Tabel 1, siswa setuju bahwa media power point praktis dan mudah digunakan dengan besaran persentase yaitu $56 \%$.

9) Media power point efektif dalam pembelajaran materi animalia.

Tabel 1 menunjukkan bahwa siswa setuju bahwa media power point efektif dalam Pembelajaran materi animalia karena di dalam Tabel 1 menunjukkan persentase yang paling besar adalah setuju dengan persentase $44 \%$.

10) Media power point tidak memerlukan ruang penyimpanan yang besar.

Berdasarkan Tabel 1 terlihat bahwa siswa setuju bahwa media power point tidak memerlukan ruang penyimpanan yang besar karena persentase terbesar adalah setuju dengan besaran persensate $64 \%$.

Berdasarkan pertanyaan nomor 1 dan nomor 5 yang merajuk pada rasa bersemangat dan menambah motivasi belajar siswa terhadap penggunaan media power point, didapatkan hasil setuju dengan persentase yang paling tinggi yaitu 60\%, hasil ini menunjukkan bahwa siswa merasa bersemangat dan memilki motivasi belajar yang tinggi saat guru menggunakanan media pembelajaran power point.

Program power point memiliki fitur yang beragam sehingga guru dapat berkreasi membuat media pembelajaran yang menarik. Sejalan dengan pertanyaan nomor 3 didapatkan hasil dengan persentase $64 \%$ siswa setuju bahwa Power Point yang dikirimkan guru menarik. Program Power Point juga mampu untuk memvisualisasikan suatu objek pembelajaran pada materi animalia misalnya ditayangkannya gambar-gambar untuk memudahkan siswa dalam memahami dan mengenal semua spesies dari kingdom animalia.

Pertanyaan nomor 3 memperoleh hasil $44 \%$ siswa setuju bahwa penggunaan media power point mendukung pembelajaran jarak jauh. Pertanyaan ini didukung dengan pertanyaan nomor 7, 8 dan 10 yaitu media power point tidak membutuhkan banyak kuota 
untuk mengaksesnya, media power point juga praktis, dan mudah digunakan, serta tidak memerlukan ruang penyimpanan yang banyak.

Dalam pembelajarn materi animalia media pembelajaran power point dikatakan efektif digunakan, pendapat ini didukung dengan hasil penelitian Hikmah (2020:16) menyatakan bahwa media pembelajaran power point dapat menarik minat belajar siswa sehingga mendapatkan hasil yang memuaskan. Tampilan media pembelajaraan yang menarik tentunya penting mendapat perhatian dari guru. media power point menunjang tersedianya media pembelajaran yang menarik namun juga praktis digunakan.

Media pembelajaran power point mampu menunjang pembelajaran jarak jauh, agar pelaksanaan proses pembelajaran menjadi lebih mudah disampaikan. pembelajaran jarak jauh dilakukan pada masa pandemic COVID-19 saat ini. Penggunaan media pembelajaran power point dianggap media yang paling memungkinkan untuk menunjang terlaksananya pembelajaran agar tujuan pembelajaran juga tetap tercapai.

Menurut Maryatun (2015 : 15) media power point memiliki penyajiannya menarik karena ada permainan warna, huruf, dan animasi baik animasi gambar maupun foto, lebih merangsang anak mengetahui lebih jauh informasi tentang bahan ajar yang tersaji, pesan informasi Tampilan visual mudah dipahami peserta didik dan tenaga pendidik tidak perlu banyak menerangkan bahan ajar yang sedang disajikan.

Oleh karena itu penggunaan media power point masih menjadi media yang relevan untuk dikembangkan khususnya di masa pandemi. Kekuatan media power point terletak pada penulisan isi yang efektif, variasi penggunakan berbagai gambar dan animasi, sehingga dapat menjadi sesuatu yang menarik bagi peserta didik. Pengembangan lebih lanjut diharapkan media powerpoint menjadi media yang lebih interaktif seperti dengan tambahan bagian latihan menjawab pertanyaan atau juga dengan penambahan suara audio yang lebih menyenangkan.

\section{SIMPULAN}

Berdasarkan data hasil penelitian dan pembahasan yang telah dipaparkan dapat disimpulkan bahwa media pembelajaran power point masih relevan digunakan dalam pembelajaran materi animalia kelas VIII di SMP Negeri 1 Pandak, Media pembelajaran ini 
juga memudahkan siswa dalam pembelajan jarak jauh di masa Pandemi COVID 19 karena sifatnya yang praktis, mudah digunakan, memilki ukuran file yang kecil dan tidak memerlukan banyak kuota untuk mengaksesnya.

Hasil pembelajaran menggunakan power point secara umum dapat meningkatkan semangat pembelajaran, memahami materi, menarik untuk media pembelajaran. Namun demikian beberapa responden masih menganggap ragu-ragu, oleh karena itu perlu mengembangkan variasi media power point, selain itu juga perlu pengujian secara eksperimen antara penggunaan media power point biasa dibandingkan dengan media digital lainnya seperti video pembelajaran digital dan pembelajaran online melalui googlemeet atau zoom. Pembahasan dalam penelitian ini juga masih memiliki keterbatasan dalam menelusuri alasan pilihan jawaban, oleh karenanya perlu penelitian lebih lanjut untuk mengetahui alasanalasan peserta didik dalam memilih tidak setuju, setuju atau sangat setuju.

\section{DAFTAR PUSTAKA}

Azhar, R. (2017). Pengembangan Media Pembelajaran Interaktif Berbasis Microsoft Power Point pada sistem Koordinat Kartesius. Aceh: Akademi Komunitas Negeri Pidie Jaya.

Detik News. (2020). Tambah 4.496, Kasus Corona di RI 26 Septemberi 2020 Jadi 271.339. Retrieved September 26, 2020, from https://news.detik.com/berita/d

Hikmah, S. N., Maskar, S., \& Indonesia, U. T. (2020). Pemanfaatan Aplikasi Microsoft Powerpoint Pada Siswa Smp Kelas VIII Dalam Pembelajaran Koordinar Kartesius. Jurnal Ilmiah Matematika Realistik. 1(1), 15-19.

Kemendikbud. (2020). Pusat Pendidikan dan Pelatihan Pegawai Kementrian Pendidikan dan Kebudayaan.https://pusdiklat.kemdikbud.go.id/surat-edaran-mendikbud-no-4tahun2020-tentang-pelaksanaan-kebijakan-pendidikan-dalam-masa-daruratpenyebarancorona-virus-disease-covid-1-9/

Maryatun, M. (2015). Pengaruh Penggunaan Media Program Microsoft Powerpoint Terhadap Hasil Belajar Strategi Promosi Pemasaran Mahasiswa Semester 2 Program Studi Pendidikan Ekonomi Universitas Muhammadiyah Metro Tahun Ajaran 2014/2015. PROMOSI (Jurnal Pendidikan Ekonomi), 3(1), 1-13.

Susilo, A., Rumende, C. M., Pitoyo, C. W., Santoso, W. D., Yulianti, M., Sinto, R., ... Cipto, R. (2020). Coronavirus Disease 2019 : Tinjauan Literatur Terkini Coronavirus Disease 2019: Review of Current Literatures. Jurnal Penyakit Dalam Indonesia, 7(1), 45-67. 
Suswandari, M., Veteran, U., \& Nusantara, B. (2020). Pengaruh Daring Learning terhadap Hasil Belajar IPA Siswa Sekolah Dasar. Prosiding. Sukohajo : Universitas Veteran Bangun Nusantara Sukoharjo

Yuliana. (2020). Corona virus diseases (COVID-19); Sebuah tinjauan literatur. Wellness and Healthy Magazine, 2(1), 187-192. 